\title{
VNITŘNÍ PŘEDPISY, JEJICH „VNĚJŠI'“ ÚČINKY A JINÉ PROBLEMATICKÉ ASPEKTY
}

\author{
KATEŘINA FRUMAROVÁ
}

\begin{abstract}
Internal Regulations, Their "External" Effects and Other Problematic Aspects
The article deals with internal regulations, which represent one of the traditional forms of public administration activities. It examines which issues may be subject to internal regulations and which issues may not. Furthermore, the author pays particular attention to the analysis of whether internal regulations can also have external effects in relation to addressees of public administration. Finally, the article also draws attention to other problematic aspects related to the issuing of internal regulations, which are mainly caused by their minimalist legislation.
\end{abstract}

Keywords: public administration; forms of aktivity; internal regulations; administrative practice; legitimate expectations; binding force

Klíčová slova: veřejná správa; formy činnosti; vnitřní předpisy; správní praxe; legitimní očekávání; závaznost

DOI: $10.14712 / 23366478.2020 .9$

\section{1. ÚVOD}

Vnitřní předpisy neboli interní normativní akty (instrukce) představují jednu z významných forem činnosti veřejné správy. Jde o akty abstraktní povahy, které jak plyne již z jejich označení - působí svými účinky primárně dovnitř systému veřejné správy. Článek se však - vedle jejich možného obsahu - zaměřuje zejména na to, zda i přes toto své označení a funkci směřují jejich účinky i vně, tj. ve vztahu k adresátům. A pokud ano, tak v jakém rozsahu, s jakými důsledky a za jakých podmínek. Současně je třeba konstatovat, že obsahová i procedurální stránka vydávání vnitřních předpisů je upravena právním řádem pouze minimálně. $Z$ toho samožrejmě plynou další problematické aspekty, na které se snaží článek taktéž poukázat.

\section{VNITŘNÍ PŘEDPISY - TRADIČNÍ FORMA ČINNOSTI VEŘEJNÉ SPRÁVY}

Veřejná správa je formální organizací a jako každá organizace, resp. organizační jednotka potřebuje ke své existenci a řádnému chodu regulaci v podobě určitých pravidel. Vedle právních předpisů plní tuto funkci též předpisy vnitřní. Vydává je sama veřejná správa, tedy svým způsobem sebe samu zavazuje a reguluje. S ohledem na roz- 
sáhlost organizační struktury veřejné správy a současně rozmanitost činností a úkolů, které plní a obstarává, lze konstatovat, že by se bez nich neobešla. Přesto, že jde o jednu z typických a tradičních forem činnosti veřejné správy, není jí v odborné literatuře věnováno tolik pozornosti jako např́ílad správním aktů, či právním předpisům. Vyšší zájem (nejen ze strany) správní nauky o tuto problematiku je však žádoucí, a to i proto, že vydávání vnitřních předpisů a jejich aplikace je spojena s řadou problémů. Otázkou je samo o sobě již to, které akty do této kategorie lze zařadit, upozorňováno je především na směšování těchto aktů a statutárních předpisů. ${ }^{1}$ Naprostá nejednotnost panuje v terminologii, zpravidla absentuje výslovné zákonné zmocnění pro jejich vydání, jakož i úprava procedury jejich přijetí, včetně publikace, ale i úprava kontroly zákonnosti vnitřních předpisů a způsob nápravy prŕípadných vad. Vedle procedurální stránky nebývá př́lilš specifikována ani jejich stránka obsahová a sporné mohou být především jejich účinky navenek, tj. ve vztahu k extraneům.

Přesto jsou a byly vnitřní předpisy vždy neoddělitelnou součástí fungování veřejné správy, a to nejen stávající české, ale i té československé. Prvorepubliková nauka je označovala nejčastěji jako správní nařízení či instrukce. ${ }^{2} \mathrm{~F}$. Weyr je charakterizoval jako „obecně závazný návod či poučení, kterého se dostává jedním úredním orgánem druhému o tom, jak dlužno určitou věc nebo skupinu věcí vyř́diti" ${ }^{3}$ podle J. Hoetzela „upravuji zařizení a činnost státní, dotýkaji se interna státního organismu“. ${ }^{4}$ Také v období mezi lety 1948 až 1989 byly vnitřní předpisy předmětem zájmu správního práva a představovaly významný regulátor fungování tehdejší státní správy. Pozornost jim věnoval ve svém rozsáhlém článku ve Správním právu B. Voženílek, přičemž je označoval pojmem vnitřní (interní) normativní instrukce. I on je charakterizoval jako akty, které zavazují jen podř́zené orgány či organizace, popř. pracovníky, a považoval je za určité „,neoficiálni" prameny správního práva. ${ }^{5}$

Ani po roce 1989, kdy se Česká republika znovu stala demokratickým právním státem, neztratily vnitřní předpisy na své důležitosti či četnosti. Přední představitelé současné správní nauky je poměrně shodně vymezují jako „akty abstraktní povahy, ${ }^{6}$ které slouži k uspořádání poměrů uvnitř jedné nebo více organizačnich jednotek nebo zařizení veřejné správy a jejichž vydáni se opírá o právně zakotvený vztah podřizenosti $k$ vydavateli aktu" ${ }^{7}$ Ani v současné době bohužel nepanuje jednoznačnost co do terminologie a označení této skupiny aktů, lze se setkat nejen s názvem vnitřní předpisy, ale i interní normativní akty (či předpisy), správní nařízení (zpravidla s odkazem na

1 HENDRYCH, D. Vnitřní předpisy. In: HENDRYCH, D. a kol. Správní právo. Obecná část. 9. vyd. Praha: C. H. Beck, 2016, s. 130.

2 Srov. MERKL, A. Obecné právo správní. Díl první. Praha - Brno: Orbis, 1931, s. 9; WEYR, F. Instrukce. In: Slovník československého práva veřejného, sv. II. Praha: Eurolex Bohemia, 2000, s. 11; HOETZEL, J. Československé správní právo. Část všeobecná. Praha: Melantrich, 1934, s. 43.

3 WEYR, c. d., s. 11.

4 HOETZEL, c. d., s. 43.

5 VOŽENÍLEK, B. Př́ispěvek k teorii vnitřních normativních instrukcí v československé socialistické státní správě. Správní právo, 1974, č. 6, s. 404; shodně LUKEŠ, Z. K otázce přípravy legislativních návrhů. Správní právo, 1973, č. 1, s. 43.

6 Znak abstraktnosti odlišuje interní normativní instrukce od tzv. individuálních služebních pokynů.

7 HENDRYCH a kol., c. d., s. 131; obdobně KOPECKÝ, M. Správní právo. Obecná část. Praha: C. H. Beck, 2019, s. 148; SLÁDEČEK, V. Obecné správní právo. 4. vyd. Praha: Wolters Kluwer ČR, 2019, s. 77; PRŮCHA, P. Správní právo. Obecná část. 8. vyd. Brno - Plzeň: Aleš Čeněk, 2012, s. 275. 
prvorepublikovou doktrínu), a další. ${ }^{8}$ Také judikatura vymezuje tyto akty podobně jako správní nauka. Např́klad dle Ústavního soudu ,určujícím znakem interních instrukcí je to, že se jimi jen konkretizují úkoly a povinnosti podř́zených složek a pracovníků. Vydáváním interních instrukci se realizuje oprávnění rídit činnost podřizených. "9 Nejvyšší správní soud ve vztahu k nim uvádí, že vydávání instrukcí (interních pokynů, směrnic apod.) nadřízeným orgánem je pouhou realizací oprávnění řídit činnost podřízených a jejich plnění je zachováváním právní povinnosti řídit se ve služební činnosti př́ikazy nadřízených. Tato oprávnění vyplývají z právní normy, jež stanoví vztah nadřízenosti a podřízenosti; interními instrukcemi se proto jen konkretizují úkoly a povinnosti podř́zených složek a pracovníků. ${ }^{10}$

\section{K PODSTATĚ, ÚČELU A ZEJMÉNA K ÚČINKU゚M VNITŘNÍCH PŘEDPISŮ}

Jak plyne z výše uvedených charakteristik podaných naukou i praxí, primární podstatou a účelem vnitřních předpisů je zajistit - a to působením „dovnitř‘ systému - řádný výkon veřejné správy, a to jak ve smyslu její organizace, tak i činnosti. Vnitřní předpisy tedy směřují svými účinky především dovnitř samotného systému veřejné správy, jejich primárními adresáty (ne však jedinými - jak bude poukázáno níže) jsou samotné orgány veřejné správy, potažmo její konkrétní pracovníci. Jde o určitá vnitřní pravidla, která mají zajistit, aby byly zákonně, věcně správně a efektivně naplňovány cíle a úkoly veřejné správy, a to v souladu s dalšími základními zásadami (jako je rychlost, hospodárnost atd.).

Poněvadž jde o akty, které nejsou právem téměř vůbec upraveny, tak ani obsah vnitřních předpisů není nijak blíže vymezen. ${ }^{11}$ Přesto se snaží především nauka jejich obsah vymezit a dle něj tyto akty systematizovat. Např́íklad J. Hoetzel s odkazem na Anschutze uvádí tuto klasifikaci vnitřních předpisů: organizační (mající za předmět úpravy zařízení státních úřadů), ústavové (regulující zařízení, správu a užívání státních ústavů) ${ }^{12}$ a konečně služební (obsahující nařízení vyššího orgánu nižšímu, jak si má počínati). ${ }^{13}$ B. Voženílek pak rozlišuje podle předmětu úpravy instrukce, které (1) upravují vnitřní organizaci správních orgánů, (2) upravují vnitřní chod práce (služby) správního orgánu, (3) pro vnitřní potřebu správních orgánů konkretizují ustanovení právních předpisů a stanoví pokyny pro jejich aplikaci, (4) upravují činnost a hospodaření jednotek zř́zených správními orgány. ${ }^{14}$

\footnotetext{
8 V. Šemora hovoří v tomto směru o tzv. soft law. Viz ŠEMORA, V. K některým aspektům právně nevynutitelných nástrojů (soft law) vydávaných správními orgány. Právní rozhledy, 2011, č. 2, s. 48 a násl.

9 Nález Ústavního soudu (ÚS) ze dne 5. 4. 1994, sp. zn. Pl. ÚS 49/93.

10 Srov. rozsudek Nejvyššího správního soudu (NSS) ze dne 17. 1. 2007, sp. zn. 5 As 28/2007.

11 Byt' existují výjimky - srov. např. zákon č. 234/2014 Sb., o státní službě.

$12 \mathrm{~V}$ současné době někteří autoři podřazují provozní a ústavní řády pod vnitřní předpisy (např. HENDRYCH a kol., c. d., s. 131), naopak jiní je staví vedle vnitřních předpisů (srov. KOPECKÝ, c. d., s. 148).

13 HOETZEL, c. d., s. 43.

14 VOŽENÍLEK, c. d., s. 412 a násl.
} 
Domnívám se, že lze především rozlišovat vnitřní předpisy regulující organizaci veřejné správy a vnitřní předpisy vztahující se $\mathrm{k}$ činnosti veřejné správy (tj. $\mathrm{k}$ výkonu její působnosti a pravomoci). $Z$ jiného úhlu pohledu lze poukázat na to, že obsah jedné části těchto aktů bude normativního charakteru (tedy půjde o pravidla chování, avšak pouze $\mathrm{v}$ podobě vnitřních, nikoli právních norem), zatímco obsah zbylé části vnitřních předpisů bude „nenormativni“", tj. nebude mít charakter regulativní (v podobě normy), ale pouze proklamativní, informativní a osvětlující, apod. (např. shrnutí určitých informací, různá prohlášení, doporučení). Lze mít za to, že převažovat budou vnitřní předpisy normativního charakteru, přičemž může jít jak o normy zavazující, tak i opravňující své adresáty k určité činnosti, postupu, apod. S ohledem na minimální právní úpravu a limitaci obsahu vnitřních předpisů vyvstává zásadní otázka, a to: co vše si (ne)může veřejná správa upravit a stanovit v podobě vnitřních předpisů.

Zřejmě nejvíce problematická $\mathrm{v}$ tomto ohledu může být skupina vnitřních předpisů zaměřená na činnost veřejné správy, resp. zejména na konkretizaci právních předpisů pro potřeby aplikace ze strany př́slušných správních orgánů a pracovníků. Právě tato skupina interních předpisů totiž může mít výrazný dopad nejen dovnitř systému veřejné správy, ale i vně, ve vztahu k jejím adresátům, jak vyplyne z níže uvedeného. Bezpochyby univerzálním a základním limitem z pohledu stanovení obsahu takovýchto vnitřních předpisů bude vždy zásada zákonnosti. Obsah vnitřních norem musí být vždy v souladu s obsahem norem právních.

To znamená, že jednak může vnitřní předpis pouze určitým způsobem shrnovat obsah (i vícero) právních předpisů (např. $z$ důvodu přehlednosti pro př́slušné orgány a jejich pracovníky). Zde by neměly vyvstávat žádné problematické aspekty. Již složitější však je skutečnost, zda vnitřní předpis může i určitým způsobem „rozvést“ a konkretizovat právní úpravu pro potřeby aplikace ze strany př́slušného orgánu(ů). Lze mít za to, že ano, nicméně je třeba respektovat určité zásady a limity. V př́padech, kdy zákonná (i podzákonná) úprava mlčí $\mathrm{k}$ určitým otázkám, které jsou součástí realizace zákonem dané pravomoci a působnosti správních orgánů, je možno tyto aspekty upravit ve vnitřních předpisech a tyto pak $\mathrm{v}$ př́slušných postupech a řízeních aplikovat, kdy - jak uvedl Nejvyšší správní soud - ,za situace, kdy zákon či predpis jej provádějici výslovně neupravují konkrétni postup správních orgánů, $k$ němuž jsou tyto orgány na základě zákona zmocněny, není v rozporu se zákonem, postupují-li dle interních předpisü. Podmínkou ovšem je, že takový interní predpis založil správní praxi, která je nepochybně a všeobecně dodržována." 15 Rozšířený senát téhož soudu pak k tomuto doplňuje, že za ustálenou správní praxi lze považovat pouze postup v intencích interního předpisu, který se nachází intra legem, a není tedy ani contra legem, ani praeter legem. ${ }^{16} \mathrm{Jde}$ o to, že právní normy jako abstraktní a obecná pravidla chování mohou dosahovat pouze určité míry konkrétnosti svého obsahu. Proto je pomocí vnitřních předpisů tento obsah dále zpřesňován a konkretizován pro potřeby aplikační praxe. Vždy však zůstává a musí zůstat určitá míra a prostor pro úvahu správního orgánu, nebot' ,zpravidla není možné úredni postup předpisem upravit natolik detailně, aby pokrýval všechny představitelné

15 Rozsudek NSS ze dne 23. 8. 2007, sp. zn. 7 Afs 45/2007.

16 Usnesení rozšířeného senátu NSS ze dne 21. 7. 2009, sp. zn. 6 Ads 88/2006. 
dillči kroky, které je třeba př́i výkonu pravomocí učinit ${ }^{\text {“ }}{ }^{17}$ Shrneme-li výše uvedené, je tedy př́pustné a začasté i žádoucí, aby vnitřní předpisy konkretizovaly obsah právních předpisů upravujících činnost veřejné správy, vždy však za př́sného respektování zásady zákonnosti, což v tomto ohledu znamená, že vnitřní předpis se svým obsahem musí pohybovat výlučně intra legem.

V souvislosti s výše uvedenou konkretizací právních předpisů vnitřními předpisy je třeba doplnit, že je však zcela vyloučeno, aby vnitřní předpisy ukládaly nové povinnosti nepodřizeným subjektům, tj. adresátům veřejné správy (a to s ohledem na ústavně právní limit zakotvený v čl. 4 odst. 1 Listiny ${ }^{18}$ ). Jak uvedl již J. Hoetzel, služební instrukce (normálky) nechtějí a nemohou zakládati pro extraney ani práva ani povinnosti, ta pro ně mohou plynouti bud' ze zákona, nebo z právních nařízení. ${ }^{19}$ Stejně tak je třeba při vydávání interních aktů respektovat čl. 4 odst. 2 Listiny, který stanoví, že meze základních práv a svobod mohou být za podmínek stanovených Listinou upraveny pouze zákonem. Proto Ústavní soud zrušil mj. ust. § 48 odst. 2 zákona o služebním poměru př́slušníků bezpečnostních sborů ${ }^{20}$ (a to ke dni 30. 7. 2019), kdy toto ustanovení znělo: Př́slušník nesmí vykonávat jinou výdělečnou činnost než službu podle tohoto zákona; toto omezení se nevztahuje na př́pady uvedené $\mathrm{v} \S 29,31$ a $\S 33$ písm. a) a na další činnosti stanovené interními akty vydanými řediteli bezpečnostních sborů. Ústavní soud zde jasně a jednoznačně konstatoval, že takovýmto způsobem nelze obcházet ústavně právní požadavek výhrady zákona. ${ }^{21}$

Taktéž i pravomoc a působnost správních orgánů lze stanovovat pouze zákonem. Základním strukturálním pravidlem pro výkon moci v právním státě je uplatňování státní, resp. veřejné moci jen v př́ípadech a v mezích stanovených zákonem, a to způsobem, který zákon stanoví. Vedle čl. 2 odst. 2 Listiny tento princip zakotvuje i samotná Ústava v čl. 2 odst. 3 , jež nadto zdůrazñuje jeho ústavní pandán - základní účel výkonu takovéto moci, jímž je služba občanům. Tento princip ve své první dimenzi představuje esenciální náležitost každého demokratického právního státu (čl. 1 odst. 1 Ústavy), bez jeho dodržení nelze vůbec hovořit o právním státu, nebot' vyloučení libovůle při výkonu veřejné moci, resp. ukládání povinností, bylo i historicky vzato první podmínkou při úvahách o formování právního státu, dokonce i pouze $\mathrm{v}$ jeho formální podobě. ${ }^{22} \mathrm{Ve}$ své druhé dimenzi pak působí jako subjektivní právo jednotlivce na to, aby veřejná moc vi̊či němu postupovala pouze tak, jak stanoví zákon. ${ }^{23}$ Žádný orgán veřejné moci se proto nesmí v demokratickém právním státě pohybovat mimo výše uvedené meze, tj. mimo svoji pravomoc a působnost, které jsou mu ústavním pořádkem, resp. zákony vymezeny. ${ }^{24}$ Výše uvedená ustanovení Ústavy a Listiny tak představují základní po-

17 Rozsudek Nejvyššího soudu ze dne 16. 8. 2000 sp. zn. 25 Cdo 1099/99.

18 Listina základních práv a svobod vyhlášená usnesením předsednictva ČNR č. 2/1993 Sb., jako součást ústavního pořádku ČR.

19 A dodává, že pro úředníka zakládají instrukce práva a povinnosti služební. Podrobněji viz HOETZEL, c. d., s. 44.

20 Zákon č. 361/2003 Sb., o služebním poměru příslušníků bezpečnostních sborů.

21 K podrobnější argumentaci srov. nález ÚS ze dne 11. 9. 2018, sp. zn. Pl. ÚS 24/17.

22 Nález ÚS ze dne 20. 11. 2002, sp. zn. I. ÚS 512/02.

23 Nález ÚS ze dne 9. 10. 2003, sp. zn. IV. ÚS 150/01.

$24 \mathrm{~K}$ tomu srov. již judikaturu prvorepublikového Nejvyššího správního soudu, jenž konstatoval: ,Kompetence úr̆adu správního může býti založena jen positivním predpisem zákona, nikdy pouhou analogii."“ 
jistku proti výkonu libovůle (či zvůle) ze strany veřejné moci ve vztahu $\mathrm{k}$ jejím adresátům. ${ }^{25}$ Proto i př́padná delegace rozhodovací pravomoci na základě vnitřních předpisů musí být předvídána zákonem, jinak se jedná o nezákonný, resp. protiústavní postup. ${ }^{26}$ Lze v tomto ohledu souhlasit s Nejvyšším správním soudem, podle kterého „na základě zákonných kompetenčních norem mohou být mocenská oprávněni k rozhodování dále konkretizována prostřednictvím norem podzákonných, ale také internich norem, služebních pokynů a předpisů (tzv. aktư ř́zení) v rámci organizační struktury instituce pověřené výkonem veřejné moci prostřednictvím výkonu rozhodovací pravomoci ve veřejné správě. Podmínky ústavnosti a zákonnosti takových zmocnění jsou zachovány pouze tehdy, pokud existuje zákonná právní norma, která k delegaci rozhodovacích oprávnění prostřednictvím podzákonného či služebniho předpisu poskytuje zákonné zmocnění،"27 Typicky se vnitřní předpisy delegující rozhodovací pravomoc vyskytují v oblasti bezpečnostních sborů či správy obrany.

Konečně oblastí, kde je užití vnitřních předpisů také výrazně limitováno, je oblast správního trestání, a to zejména s ohledem na zásadu nullum crimen, nulla poena sine lege. Jelikož správní delikt lze vymezit jako protiprávní jednání, jehož znaky jsou stanoveny zákonem, a za které je ze strany správního orgánu ukládán trest stanovený normou správního práva, není zde prostor pro vnitřní předpisy a jejich aplikaci. Je totiž nezbytné, ,aby veškeré podmínky, jež jsou pro adresáta takové normy, a tedy delikventa, závaznými a jejichž porušení je postihováno, byly obsaženy v právní normě, jež je součástí zákona, prípadně dílem i v právni normě, jež je součástí obecně závazného podzákonného předpisu, nepřekračuje-li meze, které takovému obecně závaznému podzákonnému předpisu zákon výslovně stanovil. Jinými slovy: existenci správního deliktu lze správním orgánem konstatovat a konkrétni subjekt lze za spáchání takového správního deliktu postihnout toliko tehdy, jsou-li jednánim, ježje v rámci správního ř́zeni zjištěno, naplněny všechny znaky deliktu, které jsou podávány z konkrétni skutkové podstaty obsažené v zákoně, pritom nanejvýš lze připustit doplněni zákonem stanovených podminek v podzákonném obecně závazném právním předpisu, a to výhradně způsobem zákonem stanovený rámec nepřekračujicím. “28 Výrok o vině, nebo trestu za správní delikt se tedy musí vždy opírat o právní, nikoli interní předpis. Porušení ustanovení vnitřních předpisů nemůže založit odpovědnost za správní delikt, vyjma př́padů, kdy to výslovně stanoví zákon (srov. např. § 87 a násl. zákona o státní službě, dle kterého je kárným proviněním

Viz nález Nejvyššího správního soudu Boh. A 5753/26; shodně též nález Boh. A 6931/27, 10990/34, $11100 / 34$.

25 Podrobněji viz WAGNEROVÁ, E. In: WAGNEROVÁ, E. - ŠIMÍČEK, V. - LANGÁŠEK, T. - POSPÍŠIL, I. a kol. Listina základních práv a svobod. Komentáŕ. Praha: Wolters Kluwer ČR, a. s., 2012, s. 87 a násl.; či ŠIMÍČEK, V. In: BAHÝĹOVÁ, L. - FILIP, J. - MOLEK, P. - PODHRÁZSKÝ, M. - SUCHÁNEK, R. - ŠIMÍČEK, V. - VYHNÁNEK, L. Ústava České republiky. Komentár. Praha: Linde, 2010, s. 56.

26 Již prvorepubliková správní nauka i judikatura konstatovala, že „zákonná kompetence orgánu nemůže býti účinně delegována orgánu jinému, pokud to nějaká právní norma výslovně nepřipoušti “. KLIMENT, J. - ZEIS, E. Československé správni řizení. Praha: Právnické knihkupectví a nakladatelství V. Linhart, 1937, s. 48 a násl. Srov. též nález Nejvyššího správního soudu Boh. A 7549/28. Shodně i současná judikatura - viz nález ÚS ze dne 9. 10. 2003, sp. zn. IV. ÚS 150/01.

27 Rozsudek NSS ze dne 11. 4. 2019, sp. zn. 6 Ad 13/2016, či rozsudek NSS ze dne 24. 9. 2013, sp. zn. 4 Ads $118 / 2012$.

28 Rozsudek NSS ze dne 23. 9. 2004, sp. zn. 6 A 173/2002. 
zaviněné porušení služební kázně, přičemž služební kázní se rozumí mj. i dodržování a plnění povinností stanovených státnímu zaměstnanci služebními předpisy).

Předmětem vnitřních předpisů může být i výklad obsahu právních předpisů. $\mathrm{V}$ tomto ohledu však musí být tvưrce vnitřního předpisu velmi precizní, nebot' se nesmí jednat ani o interpretaci př́liš zužující, či naopak jdoucí nad rámec plynoucí z právního předpisu. Je také prrípustné, aby předmětem interního předpisu byl výklad usměrňující aplikaci neurčitého právního pojmu. Správní praxe v tomto ohledu připouští, že kontinuálně se opakující výklad neurčitého právního pojmu může založit tzv. správní praxi. Nicméně tato skutečnost nikdy nezbavuje správní orgán povinnosti neurčitý právní pojem interpretovat vzhledem ke konkrétním skutkovým okolnostem každého jednotlivého př́padu a své úvahy, kterými se při výkladu neurčitého pojmu řídil, uvést v odůvodnění svého rozhodnutí. Této povinnosti nejsou správní orgány zbaveny podle judikatury ani tehdy, pokud je výklad správních orgánů založen na správní praxi, která se při jeho interpretaci vyvinula, třebaže lze připustit, ,že obecně platná argumentace může být nahrazena napr. i odkazem na veřejně prístupný dokument, který zavedenou správní praxi veřejnosti vysvětluje “. ${ }^{29} \mathrm{~K}$ tomuto je třeba ale dle mého názoru doplnit, že sice odkaz na zavedenou správní praxi může být součástí odůvodnění rozhodnutí, nicméně nemůže v plném, resp. dostačujícím rozsahu nahradit konkrétní odůvodnění toho, proč byl v daném prŕípadě neurčitý právní pojem interpretován tak, jak byl, a jakými úvahami se správní orgán při jeho výkladu řídil s ohledem na konkrétní případ.

Vedle stránky obsahové je značně problematické také jednoznačně vymezit a osvětlit účinky vnitřních předpisů. Je nepochybné, že interní předpisy vždy primárně zavazují podřízené orgány či pracovníky. Tito jsou povinni je respektovat a aplikovat, byt' se nejedná o obecně závazné právní předpisy. Povinnost se jimi řídit (stejně jako oprávnění je vydávat) vyplývá z právní normy stanovící vztah nadřízenosti a podřízenosti. ${ }^{30}$ To ostatně potvrzuje i judikatura, když uvádí: „Přestože pokyny ministerstev nejsou obecně závaznými právními předpisy, správni orgány mají povinnost se jimi ve své právní praxi ř́dit, což neplatí pouze v př́padě, že by se taková praxe neslučovala s obecně závaznými právními préedpisy. "31 Z toho lze dovozovat, že každý dotčený pracovník by měl vždy posoudit soulad vnitřního předpisu, který má aplikovat, s právními předpisy, tedy posoudit jeho zákonnost. Tuto možnost naopak nemá už ve vztahu k podzákonným právním předpisům, které taktéž vydává sama veřejná správa, a samozřejmě ani k zákonům. ${ }^{32}$ Jak by měl v takové situaci postupovat, upravuje např. $\S 85$ zákona o státní službě, ${ }^{33}$ kde je upraven postup státního zaměstnance pro př́ípad, kdy má za to, že je př́kaz mu daný v rozporu se zákonem, přičemž se má obdobně postupovat i v situaci, kdy má zaměstnanec za to, že je v rozporu se zákonem služební předpis. Také zákon

29 Rozsudek Krajského soudu v Praze ze dne 28. 1. 2016, sp. zn. 47 A 22/2013.

30 Specificky je upravena vázanost usneseními vlády, kdy zákon č. 2/1969 Sb. výslovně v § 21 stanoví, že ministerstva se ve veškeré své činnosti řídí ústavními a ostatními zákony a usneseními vlády. Usnesení vlády ale samozřejmě nemusí být vždy jen vnitřním předpisem (je třeba vycházet z jeho obsahu).

31 Rozsudek NSS ze dne 16. 8. 2010, sp. zn. 2 Afs 53/2010; shodně i ÚS v nálezu ze dne 22. 3. 2016, sp. zn. IV. ÚS 2598/15.

32 Srov. a contrario čl. 95 Ústavy ČR.

33 Zákon č. 234/2014 Sb., o státní službě. 
o služebním poměru příslušníků bezpečnostních sborů ${ }^{34}$ upravuje v $\S 46$ postup v případě, kdy je rozkaz vydán v rozporu s právními předpisy, a byt' to nestanoví výslovně jako zákon o státní službě, zřejmě by se analogicky mělo postupovat opět i v př́padech, kdy je v rozporu se zákonem služební předpis.

Působení, resp. účinky vnitřních předpisů směrem dovnitř systému veřejné správy jsou tedy relativně jednoznačně identifikovatelné. Působí však tyto akty i vně veřejné správy? Tj. ve vztahu k extraneům? A pokud ano, tak jak a za jakých podmínek? A mohou těmto osobám zakládat i subjektivní veřejná práva a povinnosti?

Byt' př́ídomek ,interní“ či „,vnitřní“ jednoznačně určuje, jaké je primární zaměření těchto aktů, nelze jim odepřít i účinky vně systému veřejné správy. Již z výše popsaného obsahu těchto aktů se podává, že logicky musí působit i navenek, tedy ve vztahu k adresátům veřejné správy. Ostatně i judikatura poukazuje na tyto účinky, kdy např́íklad v rozsudku ze dne 30. 4. 2008, sp. zn. 4 As 20/2007 Nejvyšší správní soud zdůraznil, že obsahuje-li akt metodického řízení výklad určitých ustanovení zákona, nebo dokonce konkrétní požadavky na účastníka řízení, které nejsou v zákoně či jiném právním předpisu explicitně vyjádřeny, ,nelze pochybovat o tom, že se takovýto předpis - jakkoli označovaný za vnitřni - třetích osob př́mo dotýká،. Lze proto shodně - i z pohledu doktríny - konstatovat, že vnitřní předpisy zejména tohoto obsahového zaměření mohou vcelku výrazně zasahovat do poměrů adresátů veřejné správy. Pokud totiž tyto osoby realizují určitá práva či plní povinnosti, je začasté potřeba, aby v rámci příslušného procesního postupu respektovaly a zohlednili nejen obsah relevantních právních předpisů, ale i těch vnitřních.

Vcelku zásadní dopad má z tohoto úhlu pohledu zejména utváření ustálené rozhodovací praxe správních orgánů, a to právě na základě opakované ustálené aplikace těchto vnitřních norem v druhově obdobných případech. Takováto správní praxe, vytvoří-li se, je pro správní orgány zavazující, tj. musí ji respektovat a rozhodovat v obdobných př́padech obdobně. Na straně adresátů veřejné správy se pak toto projeví jako legitimní očekávání takového postupu, resp. praxe. Ovšem za jakých podmínek má ustálená správní praxe tyto účinky - tj. vázanost správního orgánu touto praxí a legitimní očekávání adresáta, že podle ní bude postupováno i v jeho př́ípadě? Musí jít jednak o situaci, kdy interní předpis upravuje postup, který není jinak obecně regulován závazným pravidlem chování (tedy zákonem či podzákonným právním předpisem). Za druhé musí být tento postup užíván opakovaně, pro případy stejného či obdobného druhu, a takto „Založená“ správní praxe musí být „,nepochybně a všeobecně“ dodržována. ${ }^{35}$ Za třetí, postup upravený v intencích vnitřního předpisu se musí nacházet vždy intra legem, a nesmí být ani contra legem, ani praeter legem. Takovouto závaznou správní praxi lze tedy na základě výše uvedeného definovat pomocí dvou kritérií: 1. kritéria zákonnosti musí se jednat výhradně o praxi (činnost, př́p. nečinnost), která je stanovena v souladu se zákonem, resp. vytvořena na základě zákonem svěřené pravomoci, přičemž nesmí zasahovat do zákonem zaručených práv soukromých osob, a 2. kritéria předvídatelnos-

\footnotetext{
34 Zákon č. 361/2003 Sb., o služebním poměru příslušníků bezpečnostních sborů. Obdobná úprava je i v zákoně č. 221/1999 Sb., o vojácích z povolání (§ 48 odst. 3).

35 Srov. k tomu např. rozsudek NSS ze dne 23. 8. 2007, sp. zn. 7 Afs 45/2007.
} 
ti - praxe je ze strany př́ślušných správních orgánů všeobecně přijímána a dodržována, je možné legitimně očekávat stejný postup v podobných př́padech. ${ }^{36}$

Řádné vymezení toho, co je a není ustálenou rozhodovací praxí, je zásadní, nebot' existuje-li, je jí správní orgán vázán. Princip vázanosti správního orgánu vlastní správní praxí, jestliže se taková praxe vytvořila, vyplývá ze zásady zákazu libovůle a neodůvodněně nerovného zacházení, tedy ze základních principů právního státu (srov. čl. 1 odst. 1 Ústavy). ${ }^{37}$ Tento ústavní princip, jejž musí veřejná správa respektovat, je vyjádřen i na úrovni podústavního práva $\mathrm{v} \S 2$ odst. 4 in fine správního rádu. ${ }^{38}$ Lze tedy shrnout slovy Nejvyššího správního soudu, že správní praxe zakládající legitimní očekávání je ,ustálená, jednotná a dlouhodobá činnost (př́p. i nečinnost) orgánů veřejné správy, která opakovaně potvrzuje určitý výklad a použití právnich predpisů. Takovou praxí je správní orgán vázán. Jen taková správni praxe je doplněním psaného práva a je zpưsobilá modifikovat pravidla obsažená v právni normě." ${ }^{39}$ Takováto ustálená praxe, založená i pouze „vnitřním předpisem“ pak nastoluje ve vztahu ke třetím osobám legitimní očekávání, že bude tímto způsobem postupováno i ve vztahu k nim, a tudíž má tak významný dopad do právní sféry osob stojících zcela mimo působnost těchto vnitřních norem. Jestliže taková praxe existuje, plyne z toho pro adresáty nárok na to, aby správní orgán podle této praxe postupoval, a nečiní-li tak, lze se domáhat ochrany jak v rámci systému veřejné správy (včetně opravných prostředků), tak i v rámci soudnictví. Jak správní soudy, tak i Ústavní soud posuzují v konkrétních případech postup správních orgánů i podle vnitřních předpisů.

Jak například uvedl v jednom ze svých rozhodnutí Nejvyšší správní soud, „,není v rozporu se zákonem, pokud za situace, $k d y$ obecně závazný právní předpis výslovně neupravuje postup správních orgánů, $k$ němuž jsou tyto zmocněny na základě zákona [v predmětné věci § 115 pism. b) zákona ČNR č. 13/1993 Sb., celního zákona], správní soud přezkoumá postup celních orgánů i z hlediska jeho souladnosti s vnitřním předpisem vydaným Generálním ředitelem Generálniho reditelství cel (SPČ 1/2000 - Pracovní postup při manipulaci se vzorky zboži k zajištěni jeho totožnosti, určení sazebního zatř́dèni a ke zjištěni jeho vlastností), který není jinak obecně právně závazný. Podmínkou ovšem je, že tento interní předpis upravuje postup, který jinak není regulován obecně závazným pravidlem chování a založil správni praxi při manipulaci se vzorky zboží, která je nepochybně a všeobecně dodržována. Správní orgán se pak od této správní praxe nemůže v jednotlivém připadě odchýlit, nebot takový jeho postup by byl libovůlí, která je v právním státě (čl. 1 odst. 1 Ústavy České republiky) nepř́ipustná.“40 To, že jsou správní orgány vázány i interními akty a jsou povinny dle nich postupovat a adresát má na tento postup nárok, plyne i z judikatury Ústavního soudu, který uvedl, že pokud správní orgány (v daném př́ípadě finanční ředitelství i Ministerstvo financí) nerespektují

36 Viz k tomu rozsudek NSS ze dne 16. 8. 2010, sp. zn. 2 Afs 53/2010.

37 Srov. k tomu rozsudek NSS ze dne 23. 8. 2007, sp. zn. 7 Afs 45/2007; rozsudek NSS ze dne 18. 1. 2011, sp. zn. 1 Ao 2/2010, či usnesení rozšířeného senátu NSS ze dne 21. 7. 2009, sp. zn. 6 Ads 88/2006.

38 Zákon č. 500/2004 Sb., správní řád.

39 Rozsudek NSS ze dne 31. 5. 2010, sp. zn. 2 Ans 1/2009, srov. též rozsudek NSS ze dne 29. 5. 2014, sp. zn. 4 Azs 92/2014.

40 Viz rozsudek NSS ze dne 23. 8. 2007, sp. zn. 7 Afs 45/2007; obdobně též ve vztahu k metodickému pokynu Ministerstva životního prostředí rozsudek NSS ze dne 18. 1. 2011, sp. zn. 1 Ao 2/2010. 
lhůty pro vyřízení věci, které jsou stanoveny v jejich vlastních normativních pokynech, dopouští se porušení práva adresáta na spravedlivý proces, resp. práva na to, aby byla věc vyř́zena a projednána bez zbytečných průtahů (dle čl. 38 odst. 2 Listiny). ${ }^{41}$

Samozřejmě je třeba doplnit, že jednou vytvořená správní praxe není neměnnou, či bez výjimek. Je-li určitá správní praxe upravena vnitřním předpisem, je přípustné (a zároveň nutné) se od ní výjimečně odchýlit v konkrétním př́ípadě, jde-li o př́ípad zvláštní a atypický. ${ }^{42}$ Důvody pro takovýto postup a individuální odchylku musí být vždy přesvědčivě a logicky odůvodněny, aby byly př́ípadně i přezkoumatelné a také přesvědčily adresáta o nezbytnosti takového odchylného postupu. Obecně se pak odchýlit od určité správní praxe, jež se vytvořila, správní orgán také může, avšak zásadně pouze pro futuro, $\mathrm{z}$ racionálních důvodů a pro všechny př́ípady, kterých se praxí zavedený postup správního orgánu dotýká. ${ }^{43}$

Konečně je třeba se také ve vztahu k vnitřním předpisům ptát, zda může mít takovýto předpis ještě zásadnější účinky ve vztahu k nepodřízeným třetím osobám. Tj. zda jim může zakládat subjektivní práva či povinnosti. Jde o otázku, kterou řešila již prvorepubliková doktrína. Již tato se jednoznačně stavěla k názoru, že vnitřní předpisy nemohou zakládat práva a povinnosti občanů. ${ }^{4}$ Taktéž prvorepublikový Nejvyšší správní soud konstantně judikoval, že tyto akty ukládají pouze určitou povinnost úřadu, ale nezakládají ,pro stranu subjektivní právo“, či že nemohou být ,pramenem subjektivních práv strany“. I současná praxe poukazuje na to, že subjektivní práva a povinnosti musí být založeny v právních, nikoli v interních předpisech: „Subjektivní práva jsou v našich podmínkách vcelku ustáleně vnímána jako práva osob, založená v právních normách (v objektivním právu).“" 45 Bezpochyby tak nelze upřít vnitřním předpisům jejich externí účinky, nicméně nelze mít za to, že by jimi mohla být založena veřejná subjektivní práva či povinnosti, a to i s ohledem na ústavně právní dimenzi této problematiky. Vcelku výstižně to vyjádřil již F. Weyr, který konstatoval: „Běžná nauka, chtějic naznačiti, že $z$ určité normy neplynou sice bezprostředně subjektivni práva pro občanstvo, ale že přece není zcela bezvýznamná pro ně, naznačuje to zpravidla povšechnějšimi a mlhavějšimi obraty, prohlašujic např., že norma dotýká se nebo může se dotýkati právni sféry, situace nebo posice stran. ${ }^{* 46}$

\section{K DALŠÍM PROBLEMATICKÝM ASPEKTU゚M SOUVISEJÍCÍM S VYDÁVÁNÍM A ÚČINKY VNITŘNÍCH PŘEDPISŮ}

Jedním z typických znaků vnitřních předpisů je skutečnost, že k jejich vydávání není třeba žádné speciální zákonné zmocnění (byt’ se s ním lze setkat ${ }^{47}$ ). Mož-

\footnotetext{
41 Nález ÚS ze dne 28. 8. 2001, sp. zn. IV. ÚS 146/01; srov. též obdobně rozsudek NSS ze dne 28. 4. 2005, sp. zn. 2 Ans 1/2005.

42 Srov. k tomu rozsudek NSS ze dne 3. 9. 2015, sp. zn. 9 Afs 310/2014.

43 Srov. v podrobnostech např. rozsudek NSS ze dne 28. 4. 2005, sp. zn. 2 Ans 1/2005.

44 Srov. WEYR, c. d., s. 12.

45 Rozsudek NSS ze dne 16. 4. 2009, sp. zn. 5 As 13/2009.

46 WEYR, c. d., s. 13.

47 Viz v tomto ohledu zejména zákon o státní službě (např. § 99 odst. 4 a další).
} 
nost či povinnost vydávat interní instrukce plyne ze vztahu nadřízenosti a podřízenosti. ${ }^{48}$ Bude tedy často záležet na přístupu konkrétních nadřízených orgánů či osob, zda a nakolik budou považovat za nezbytné upravit určité otázky v rámci vnitřních předpisů. S ohledem na to může pak samozřejmě nastat situace, kdy v některých oblastech veřejné správy bude její výkon konkretizován více a v některých méně, což může mít dopad i v rámci existence, resp. neexistence ustálené rozhodovací praxe konkrétních správních orgánů, naplňování principu legitimního očekávání i vyšší právní jistoty jedné skupiny adresátů ve vztahu k jiným. Zákonem (až na výjimky ${ }^{49}$ ) není nijak blíže upraven ani proces tvorby a přijetí vnitřního předpisu, ani jeho formální či obsahové náležitosti.

Dalším problematickým aspektem se jeví otázka publikace vnitřních předpisů. Ani tato není v rámci právní úpravy regulována (opět až na výjimky ${ }^{50}$ ), a uskutečňuje se tedy v různých formách, což ovšem může činit problémy zejména tehdy, jsou-li předmětem interních instrukcí záležitosti, které se dotýkají i osob stojících vně systému veřejné správy. V jednom ze svých rozsudků ${ }^{51}$ Nejvyšší správní soud zdůraznil, že obsahuje-li vnitřní předpis výklad určitých ustanovení zákona, nebo dokonce konkrétní požadavky na účastníka řízení, které nejsou v zákoně či jiném právním předpisu explicitně vyjádřeny, nelze pochybovat o tom, že se takovýto interní předpis dotýká třetích osob a tudíž účastník řízení či jiná dotčená osoba musí mít možnost se připravit na průběh správního řízení (či jiného postupu) a být informována o tom, co od ní bude správní orgán vyžadovat, resp. jaký výklad právního předpisu považuje správní orgán za správný tak, aby měla připraveny všechny podklady nebo shromážděny argumenty, jež bude uplatňovat. Lze tedy mít za to, že jednou z podmínek toho, aby vnitřní předpisy mohly založit ustálenou rozhodovací praxi, je i objektivní možnost adresátů se o této praxi (tj. o vnitřních předpisech a jejich obsahu) dozvědět, tj. musí být naplněno kritérium jejich publikace. ${ }^{52}$ Totéž samozřejmě platí i tehdy, dojde-li k novelizaci či ke zrušení původního a vydání nového vnitřního předpisu. Nicméně s ohledem na neexistenci jednotné publikační platformy ${ }^{53}$ lze pochybovat o skutečném naplnění tohoto požadavku v praxi a o snadné dostupnosti a povědomí adresátů o vnitřních předpisech správních orgánů na jednotlivých úsecích výkonu veřejné správy. ${ }^{54}$ Lze se domnívat, že jde o jeden z nejvýznamnějších deficitů stávající úpravy ve vztahu k vnitřním předpisům. ${ }^{55}$

Dalším problematickým aspektem, který lze opět zejména s ohledem na externí účinky vnitřních předpisů zmínit, je zajištění zákonnosti jejich obsahu. Jak bylo výše uvedeno, musí se tyto předpisy pohybovat vždy intra legem, a nikoli contra legem, ani praeter legem. Je však otazné, kdo vlastně vykonává dozor nad zákonností těchto předpisů a kdo je oprávněn, resp. povinen sjednat nápravu v př́padě, že jsou tyto předpisy

48 Rozsudek NSS ze dne 1. 12. 2010, sp. zn. 3 Ao 6/2010.

49 Srov. např. $\S 11$ a $\S 12$ zákona č. 234/2014 Sb., o státní službě.

50 Srov. např. § 61 odst. 2 písm. b) zákona č. 128/2000 Sb., o obcích (obecní zřízení); či § 92 odst. 2 zákona č. 129/2000 Sb., o krajích (krajské zřízení).

51 Rozsudek NSS ze dne 30. 4. 2008, sp. zn. 4 As 20/2007.

52 Rozsudek NSS ze dne 16. 8. 2010, sp. zn. 2 Afs 53/2010.

53 Jak uvedl ve vztahu k interním instrukcím již A. Merk1, nevyhlašují se ,podle zásad, které se uplatňují u zákonů a nařizeni". MERKL, c. d., s. 9.

54 Jak uvádí V. Sládeček, vnitřní předpisy se většinou neformálně zprostř̌edkovávají oběžníkem (per rollam), příp. vyvěšením na příslušné webové stránce. SLÁDEČEK, c. d., s. 77.

55 Shodně k tomu srov. ŠEMORA, c. d., s. 50. 
v rozporu se zákonem, tj. například jdou nad jeho rámec či upravují určité věci odchylně od zákona. ${ }^{56}$ Stejně tak je problematické i to, na koho se má obrátit adresát veřejné správy, pokud má za to, že je vnitřní předpis nezákonný. Na rozdíl od právních předpisů, kde je zajištěna soudní kontrola a možnost zrušení právního předpisu ze strany Ústavního soudu, ve vztahu k vnitřním předpisům toto neplatí. Možnost jejich zrušení ze strany (správních) soudů lze v české právní úpravě nalézt ve vztahu k služebním předpisům ( $\$ 11$ a $\S 12$ zákona o státní službě), a to v rrízení podle $\S 101$ e a násl. soudního rádu správního. ${ }^{57}$ Jinak jejich zákonnost může být přezkoumána soudem pouze v rámci rozhodování o konkrétním případu, v němž byly tyto interní akty aplikovány. Důsledkem jejich nezákonnosti však bude př́ípadně pouze zrušení konkrétního správního aktu, nikoli vnitřního předpisu jako takového. Možnosti, jak dosáhnout jejich zrušení, jsou tedy velmi omezené. Uvažovat lze pouze o zrušení takového aktu samotným jeho původcem, popř. tím, kdo je mu nadřízen (je-li takový).

Problematičnost vnitřních předpisů, resp. řady aspektů s nimi spojených dokládá závěrem jeden z nálezů Ústavního soudu: „Srovnáním Ministerstvem vnitra napadených ustanovení obecně závazné vyhlášky města Ostrova, požárního řádu města Ostrova, $s$ metodickým doporučením téhož ministerstva $k$ vydání požárnich řádio obcí, lze pak dospět k závěru, že dikce čl. 6 odst. 5 předmětné vyhlášky je identická s dikcí čl. 6 odst. 4 uvedeného metodického doporučení. Ústavni soud je tím v dané věci konfrontován s př́padem, v němž navrhovatel metodickým doporučením usměrňuje normotvornou aktivitu obcí v oblasti jejich samostatné působnosti. Pokud je ovšem doporučení akceptováno a promitnuto do textu konkrétni obecně závazné vyhlášky, navrhuje její zrušení pro rozpor s ústavním pořádkem a zákony. Ministerstvo vnitra tím vytváří situaci, jež ukazuje, že absurdní svět románů Franze Kafky či Georga Orwella, divadelních her Samuela Becketta či Eugena Ionesca nemusí být a neni toliko fikcí, nýbrž začasté je i životní realitou." 58

\section{ZÁVĚR}

Vnitřní předpisy představují tradiční a současně potřebnou součást regulace výkonu veřejné správy, a to jak z pohledu její organizace, tak i činnosti. Přestože jsou tyto akty svými účinky primárně zaměřeny dovnitř systému veřejné správy, nelze pochybovat o tom, že působí i vně tohoto systému, tj. k extraneům. Jak bylo poukázáno výše, za podmínek, že se pohybují intra legem, jsou aplikovány opakovaně a všeobecně (tj. pro všechny př́ipady podobného druhu), vytváŕí se na straně správních orgánů závazná správní praxe a na straně adresátů veřejné správy legitimní očekávání, že dle této praxe bude postupováno. Toto očekávání podléhá právní ochraně, včetně ochrany soudní.

Současně je třeba upozornit na to, že s vydáváním vnitřních předpisů je spojena řada problematických aspektů, které vyplývají zejména ze skutečnosti, že obsahová i procesní stránka týkající se těchto aktů je právními předpisy regulována jen minimálně. Jejich

\footnotetext{
6 Výjimkou je v tomto ohledu zákon o státní službě - srov. jeho $§ 12$.

7 Zákon č. 150/2002 Sb., soudní řád správní.

58 Nález ÚS ze dne 19. 9. 2006, sp. zn. Pl. ÚS 25/06.
} 
vydání často odvisí pouze od úvahy příslušného nadřízeného orgánu, absentují podrobnější pravidla upravující jejich náležitosti - a to jak formální, tak obsahové, není upraven proces jejich přijetí, včetně zásadní otázky jejich publikace. Konečně není řešena ani otázka kontroly zákonnosti těchto aktů, včetně postupu sjednání nápravy. S ohledem na to, že účinky těchto aktů zasahují nejen dovnitř, ale i vně systému veřejné správy, je třeba konstatovat, že takovýto stav by měl být de lege ferenda odstraněn, a měla by být stanovena základní obecná pravidla ve vztahu k vydávání těchto předpisů (a to jak co do jejich obsahu, tak i formy), např́klad v podobě nařízení vlády.

doc. JUDr. Kateřina Frumarová, Ph.D.

Právnická fakulta Univerzity Palackého v Olomouci

katerina.frumarova@upol.cz 